\title{
Business' Environmental Obligations and Reasoned Public Discourse: A Kantian Foundation for Analysis
}

\author{
Richard Robinson ${ }^{1} \cdot$ Nina Shah ${ }^{2}$
}

Received: 7 August 2017 / Accepted: 22 January 2018 / Published online: 3 February 2018

(c) The Author(s) 2018. This article is an open access publication

\begin{abstract}
The Kantian categorical imperative process of rational reflection and reasoned social discourse is theoretically capable of forming the moral environmental maxims applicable to business. This article argues that rational environmental discourse demands that business has an imperfect duty to develop relevant unbiased information, and perhaps to disseminate this information through participation in business-public coalitions. For the environmental problem, this "rationality" particularly concerns (i) our obligations toward future generations and distant people while recognizing that they cannot participate in current discourse, and (ii) the rules for gathering and assessing the evidence that should govern our environmental preservations and enhancements. Both these concerns demand certain scientific information requirements, as well as logical decision criteria that are perceived as stable across both overlapping generations, and affected peoples (as argued by Rawls in a different context). The criteria for Rawls' "considered moral judgments" are shown to apply to resolutions of these business-related ethical conundrums. In a way similar to Kant's anthropological examinations of humanity's antisocial behaviors, this article also examines various biases that inhibit this social reasoning.
\end{abstract}

Keywords Categorical imperative process · Perfect and imperfect duties · Environmental sustainability and enhancement · Considered moral judgments

\section{Introduction}

In debates concerning environmental norms, assertions of "the sacredness of nature" can preempt rational discourse. Attempts at this discourse can then grate on those with religious or quasi-religious commitments to the natural environment. These sorts of conflicts between assertions of dogma and the humanistic values of rational discourse, however, have been at the center of various moral debates since the Enlightenment. ${ }^{1}$ In today's public discourse they manifest one of many biases concerning environmental duty, especially with respect to business obligations. The Kantian framework for environmental duty as it applies to business

Richard Robinson

richard.robinson@fredonia.edu

Nina Shah

shah_n@telus.net

1 Department of Business Administration, SUNY at Fredonia, New York, NY, USA

2 Nicomekl Enhancement Society, Langley, BC, Canada is shown below to provide clarity to this discourse, especially as it concerns the interrelated issues of (i) the spiritual contributions of nature, (ii) our obligations to future generations, (iii) our obligations to people of distant lands, and (iv) business' potential role in the restoration of the environment.

For example, consider the question, "What does business owe the environment?" This is how the question is often put, as though nature itself must be served as an entity separate from humanity, an entity that demands our duty directly rather than as an indirect instrument that serves society. ${ }^{2} \mathrm{~A}$ subsidiary and more substantive question concerns, "Can environmental obligations be judged by business people independently of society's democratic determination?" These are relevant philosophical questions from which, perhaps, greater specification is warranted prior to any attempt

\footnotetext{
${ }^{1}$ See Inwood (1995, pp. 236-237) for a brief review of these Enlightenment debates, and Gottlieb (2016) for a more extensive review.

2 Golding (1981, pp. 62-63) described this attitude as "neopaganism" for which "the despoilment of the environment is a sacrilege of sorts." This sentiment was also expressed by Russell Train, former EPA Administrator (1970, p. 780), "If we're to be responsible, we must accept the fact that we owe a massive debt to our environment."
} 
at more practical analysis. In this light, consider the following more specific queries:

1. Does business have a duty to participate in regulatory formation that preserves or even enhances environmental integrity, and if so, what are the parameters of that participation?

2. Should business be obliged to act cooperatively to counteract the "tragedy-of-the-commons" phenomena?

3. What ethical framework is appropriate for addressing these issues?

To explore the answers to these questions, the following analysis provides a Kantian duty-based ideal that results from reasoned social discourse. For example, it is argued here that the Kantian Enlightenment approach is an appropriate and useful response to the "nature is sacred" view, and its variations. This Kantian exegesis emphasizes rational and reflective public discourse capable of establishing maxims with respect to environmental concerns, including business obligations. The parameters of that discourse as they apply to business are the subjects of this article. This is where Kantian clarity is brought to bear. It is argued here that clarity demands avoidance of certain common biases, and that agreement with respect to certain informational demands and decision criteria are necessary for this debate to be rational and moral. These obligations particularly apply to business as reviewed below.

It should be noted first, however, that by "Kantian," we mean that this analysis incorporates not only the direct philosophical contributions of Kant, but also the extensions of self-identified Kantian contributors such as John Rawls, Onora O'Neill, Allen Wood, Mark D. White, and Christine Korsgaard as examples.

\section{Further Arguments of this Article}

Any ethical framework that seeks to address the questions above ultimately poses a regulatory view of business activities, one that provides a political framework within which possible judgments of business' obligations reside. It is argued here that this framework can be provided by the Kantian philosophy of duty particularly with respect to business' contribution to reasoned social discourse that potentially allows us to reach a high degree of clarity with respect to the environmental responsibilities of business. This framework centers on notions of business' expertise, both as they exist, or ought to exist, and as applicable to its perfect and imperfect informational duties.

The argument below is composed of five broad sections. The first broad section concerns the Kantian process for forming environmental maxims. It includes the categorical imperative process and associated perfect and imperfect duties and practical limits as they might apply to environmental concerns. It also emphasizes the associated Kantian demands of rationality and public discourse. The second section argues that this rational public discourse is likely to reflect any perceived transcendent spiritual contributions of nature to humanity, as well as other environmental considerations. The third broad section applies the framework of the categorical imperative process to the problems of both intergenerational equity and people at distance as they pertain to the environment. This includes Rawlsian considerations for reaching considered moral environmental judgments. In keeping with the style of Kant's (1784b, 8:21, 1797, 6: 458-459, 6: 465-466) anthropological examinations of humanity's "unsocial sociability," the fourth section concerns the anthropology of biases that would interfere with rational moral resolutions of environmental restoration and preservation, issues that depend upon business participation. (See Wood 1999, p. 213 and White 2011, p. 112 for reviews of Kant's anthropology.) Overall, these four sections primarily concern reasoned social discourse with respect to business' environmental obligations. The fifth section presents a summary conclusion.

\section{The Process of Forming Environmental Maxims}

This section reviews those elements of Kant's categorical imperative (CI) applicable to the environmental discourse problem at hand. Such a review may be necessary for those with an incomplete Kantian background. ${ }^{3}$ It is also useful, however, for certain emphases that are not typically made in a Kantian analysis of a non-environmental sort.

Kant $(1785,1797)$ posed a categorical imperative process (CIP) built upon three interrelated formulae, each derivable from the other, and that as a group posed both (i) a personal process for forming individual moral maxims, and (ii) a social discourse process for forming societal moral maxims whether expressed by law or expressed by non-legal but nonetheless ethical norms. (See Rawls 1980, 1989, 2001 for extensive reviews and elaborations of the CIP.) Kant argued that the three interrelated formulae, presented below, express the way the common populace thinks about how our maxims should be formed. Today, this would include our environmental maxims. With respect to Formula 1 below, Kant $(1785,4$; 402) stated, "The common reason of men in its practical judgments perfectly coincides with this, and always has ..." Since the three formulae are interrelated, this "common reason of men" argument applies to all three by extension.

\footnotetext{
${ }_{3}$ Portions of this section roughly follow Robinson (2017).
} 
It is important to keep in mind that these formulae are axiomatic guides for society's reasoned discourse, from which society derives our applicable and practical duties including environmental duties ${ }^{4}$ :

Formula 1 - the formula of universal law: "Act only on maxims you would have everyone act on." (Kant 1785, 4: 402)

Formula 2 - the formula for respect for the dignity of persons: "Act so that you treat humanity, whether in your own person or in that of any other, always as an end and never as a means only." (Kant 1785, 4: 429)

Formula 3 - the formula of legislation for a moral community: "All maxims that proceed from our own making of law ought to harmonize with a possible kingdom of ends, i.e. pursuit of a moral community." (Kant 1785, 4: 433-438)

The practical maxims derived from the CIP include both perfect duty (avoiding those actions which are prohibited) and imperfect duty (those volitional actions which we should consider doing, but which have practical limits such as with actions of beneficence). ${ }^{5}$ This CIP derives our social maxims while constraining deliberations to adhere to what Kant termed the universal principle of right (UPJ):

Behave in such a way that your choices are compatible with the greatest amount of external freedom for everyone. ${ }^{6}$ (Kant 1797, 6: 230)

Note that in the three formulae and the UPJ stated above, the words everyone, humanity, any other, and community are critically germane for our examination. In this context, these CIP processes can provide our organizational view of the philosophical foundation of business' environmental obligations, whether for the individual business person, or business organizations acting in concert. For the questions at hand, there are five relevant issues posed by the CIP:

1. With respect to Kant's CI, who are the "others" (as in formula 2) included in the "everyone" (as in formula 1), and who is included in the "community" (as in for-

\footnotetext{
${ }_{4}$ Sullivan's 1994 , p. 29 interpretations from the original German are used here.

5 Kant's notion of "maxim" includes both a subjective principle of volition and an objective principle applicable to all. The former generates imperfect duty; the latter generates perfect duty. (See Kant 1797, 6: 225-226.) With respect to imperfect duty, a "maxim" requires an attitude associated with "pursuit of a moral community," but it does not specify the action that should be generated by that attitude.

${ }^{6}$ Sullivan's (1994, p. 12) interpretation is used here. In modern terminology, right is generally interpreted as justice, hence UPJ.
}

mula 3)? Do "others, everyone, and community" refer to all members of "humanity," including those at great distance from our business actions? Do they include yet unborn generations?

2. What is meant by the possible kingdom of ends in Kant's third formula? This concept is usually interpreted as pursuit of a moral community. Might this pursuit apply to the business-related environmental problems and associated reasoned discourse mentioned above?

3. Kantian philosophy is an expression of the enlightenment era, i.e., morality is centered on what humanity, after reflection and open social discourse, logically decides. It is not based on scriptural or other authoritarian decrees that might be imposed as a substitute for democratic discourse. (See Kant 1784a, 8: 35-41, 1786, 8: 146-147. Also see Wood 1999, pp. 305-306.) This poses the question, "Is nothing sacred except humanity?" Could nature be an absolute sacred entity that is separate from humanity, and therefore its preservation be itself a moral imperative that requires sacrifice of some economic or other human interests?

4. Is there within the character of humanity something paramount, so special as to be akin to scriptural sacredness, and that can be utilized for our analysis of the environmental discourse?

5. With respect to business' duty obligations of environmental concern, how does knowledge affect these obligations, and what are the imperfect obligations for acquiring and disseminating this knowledge?

These five issues are all fundamentally related to the Kantian notion of reasoned social discourse as required of the CIP for analyzing the environmental obligations of business.

\section{A Framework for Environmental Duty}

As indicated above, Kant $(1785,1797)$ claimed that his categorical imperative merely reflects common reasoning concerning the process of forming moral principles, a reasoning captured by the three formulae, reviewed above, where each is consistent with and necessitated by the other two. ${ }^{7}$ Kant's second formula (see above) is often interpreted as motivating a set of maxims we usually classify as duties, although the interrelatedness of the three formulae implies that duty can be derived from each of the three. ${ }^{8}$ It is the objective of this and the next sections to clarify some notions of these

\footnotetext{
${ }^{7}$ See O’Neill (1995), Chapters 1 and 2, and Rawls (1980, 1989) for detailed reviews of this process.

${ }^{8}$ For illustration purposes, Kant (1785, 4: 421-423) derived a set of four maxims and derived duties from the formula of universal law: maxims against suicide, the lying promise, indolence, and for charitable benevolence with practical limitations.
} 
duties as they might apply to society's reasoned discourse concerning environmental issues.

O'Neill (1995, pp. 114-115), terms the second formula "the formula of the ends-in-itself," and emphasizes its use as the foundation for perfect and imperfect duty, here applied for the purpose of environmental concerns. (The differences in these duty classifications are reviewed below.) This vision of duty is particularly applicable to business which requires a set of moral rules to function. In particular, the second formula is generally interpreted as not only establishing prohibitions against the unethical actions of theft, fraud, coercion, and the like (perfect duties of prohibition), but also as requiring a degree of volitional-based beneficent actions (imperfect duty), and these might include duties applying to environmental preservation or enhancement. Because the specification of this formula requires treating both oneself and others as ends, and not only as means, and therefore not deceiving or forcing others into serving only one's own personal ends, then imperfect duty naturally requires practical limits that Kant found in "circumstance and inclination." (See Kant 1797, 6: 454.) Without such practical limits, one could sacrifice any ability to serve one's own ends. This implies a trade-off approach that is potentially relevant to our environmental considerations as explored below. Of particular importance is to note that the focus of the CIP is on humanity and its discourse, and therefore it cannot treat the environment as a sacred entity separate from humanityrelated considerations. The environment, however, can be envisioned as instrumentally serving humanity, and therein lies its potential specialness. ${ }^{9}$

The formula of legislation for a moral community (see above) can be viewed as the motivational formula for recognizing and pursuing duty. As reviewed by Korsgaard (1996, p. 23):

The human will must be seen as universally legislative. Each of us has a will that makes laws for itself as if for everyone. Since human beings together legislate the moral law, we form a moral community: a Kingdom of Ends.... Each citizen takes his own perfection and the happiness of others as an end and treats every other as an end in itself. It is a community engaged in the harmonious and cooperative pursuit of the good. ${ }^{10}$

This vision of ethical motivation can be used as an expression of an ideal norm for a business community, and this

\footnotetext{
9 In contrast to this Kantian view that nature is an instrument of humanity, Jenkins and Chapple (2011) review the ecotheology of various religions, including Christian, Hebrew, Buddhist, Hindu, and Native American religions, all of which view nature as sacred independent of humanity, i.e., non-instrumental independent sacredness.

10 Also see Sullivan (1997, pp. 84-87) for a review similar to Korsgaard's.
}

concept of treating all as an end is shown below to form a basis for the environmental ethic where the interpretation of "all" is of paramount importance. ${ }^{11}$ Within the Kantian ethic, therefore, the motivation for environmental preservation and enhancement lies in the pursuit of the moral community, a humanity-centered motive, i.e., it would not be the pursuit of a personal nirvana of nature. This, of course, begs the question of the meaning of "a moral community," a notion explored below. For our business-environmental purposes, we can utilize Kant's explanation of his fundamental notion of applicable duty:

The duty of love for one's neighbor can, accordingly, also be expressed as the duty to make others' ends my own (provided only that these are not immoral). The duty of respect for my neighbor is contained in the maxim not to degrade any other to a mere means to my ends (not to demand that another throw himself away in order to slave for my end). $(1797,6: 450 .)^{12}$

It should suffice to point out that duty, according to Kant, serves only humanity, and not a worldly god of nature except as an instrument that serves humanity. (This exception should be of considerable importance in reasoned social discourse as emphasized below.) The Kantian notion of community is anthropocentric. ${ }^{13}$ Humanity's interconnection with nature poses duties that stem from the avoidance of degradation of respect for current humanity, but in addition, the imperative to "not degrade any other to a mere means" must apply to the degradation of future generations along with current cohorts. By permanently sacrificing the environment for the use of future generations, and for the benefits of current exploitation, we likely force a type of depravation on those as-yet-unborn. ${ }^{14}$ By benefiting from forced degradation of the habitation of others (perhaps for our current wealth enhancement), we violate the maxim of "do not degrade any other." Of course, we could ask the question concerning appropriate compensation for such degradation, but "permanent degradation" lasts a long time which makes appropriate compensation difficult to envision. Nonetheless, this possible compensation criterion is addressed in the penultimate section.

\footnotetext{
${ }^{11}$ See Robinson (2016b) for this moral community view of Kant's third formula.

12 This is a Kantian passage that fully expresses the second formula's foundation for duty. For duty of virtue based upon respect, further see Kant (1797, 6: 462).

${ }^{13}$ See Wood (1998) and O'Neill (1998) for reviews of Kantian anthropocentric philosophy.

${ }^{14}$ Mulgan (2006) considers the problem of future generations within the context of rules consequentialism, a philosophical approach different from Kantian duty philosophy.
} 
Note that Kantian deontology relies on having the appropriate motivation as necessary for moral choice, and this is germane to the environmental explorations below. It could be argued that pursuit of the moral community as motive is itself consequentialist even when one knows that actual full achievement of a moral community is impossible. The pursuit is essentially important for achieving as much of a degree of morality as possible. Without the pursuit, morality withers. The motive and the consequences cannot be entirely separated in logic as pointed out by Robinson (2016b). ${ }^{15}$

\section{Perfect and Imperfect Duties for Business' Environmental Impacts}

The analysis presented in this effort distinguishes between imperfect duty and perfect duty and explores this difference as it might apply for business' environmental consideration. Understanding the difference is essential for analysis of environmental obligations. Therefore, the following definitions apply:

- Perfect duties are absolute prohibitions against actions that violate moral maxims for respecting the dignity of persons. For example, there is an absolute prohibition against the lying promise, or fraud, or coercion, or theft, or of demonstrating contempt for the dignity of another. This includes others at a distance, and others of future generations, since both of these groups are likely to be affected by any current environmental degradation, preservation, or enhancement.

- Imperfect duties are volition-based actions in pursuit of a moral community, but that have practical limits. Beneficence, for example, must have practical limitations or the individual would not be capable of functioning in the everyday real world. These beneficent actions pose possible dutiful performance standards for business agents, standards that apply to diligence in environmental performance as explored below. ${ }^{16}$

Whereas perfect duty essentially requires non-interference with the freedom of others, imperfect duty involves beneficent action toward both others and ourselves (as specified by the second formula of the CI), and hence it has trade-offs and therefore practical limits. Perfect duties are juridical in nature and allow civilization to exist including future civilization; imperfect duties allow the community, including the business community, to flourish both now

\footnotetext{
15 See Hale (2017) for a review of the deontology versus consequentialist debate in the context of environmental ethics.

16 See Robinson (2017) for an exploration of this vision of managerial beneficence in the context of non-environmental considerations.
}

and in the future. (See Kant 1797, 6: 394.) These notions of duty should include a broad notion of community that incorporates current and future humanity, as well as people at distance.

White (2011, p. 42) suggests that imperfect duties are subject to preferences. This poses possible cost-benefit analyses for decision criteria. Kant states that imperfect duties exist because we are ".... united by nature in one dwelling place so we can help each other." (Kant 1797, 6: 453) Kant terms this "the maxim of common interest." (Ibid) This dwelling place clearly applies to the business organization as well as other groupings of family and community, but "one place" does not imply "one moment of time" or even "one geographic location." It should include future time, and given the interrelatedness of global environmental problems, then the notion of "place" should be global. It is suggested below that "common interest" must include future generations. In addition, "united by nature in one dwelling place" has obvious environmental implications. This "place" must require environmental suitability for this "dwelling".

\section{Imperfect Environmental Duty and Its Practical Limitation}

As reviewed above, according to Kant the CIP reflects common thinking about morality and how our moral maxims are formed. In this sense, people might follow this process without explicit knowledge of philosophical deontology, Kantian, or otherwise. Hence, business might follow what we classify as reasoned principles, either explicitly or at least implicitly, while recognizing that the self-worth of agents motivates them to "pursue their own morally permissible welfare and happiness, but also to promote those of others." (Sullivan 1994, p. 156) As reviewed above, for sustainability considerations, the notions of "others," "everyone," and "community" must include future generations, and people at distance, otherwise we would not recognize the CIP, and its associated formulae, as being moral.

We should view business interactions as expressions of the mutual dependence of their participants, who from an ideal Kantian perspective, we assume aim at fulfilling their own needs, and those of others. Mutual respect, however, requires that these agents treat each other not merely as the means to their own ends, but must also allow others to pursue their ends, a condition demanded by the second formula. The problem with this view, however, is that it is difficult to envision mutual dependence applying to the as-yet-unborn or distant peoples, but this apparent view is limited. Both of these groups must depend on our decisions, and our self-dignity demands that we rationally manage what we 
bequeath to them. This Kantian notion motivates the following proposition. ${ }^{17}$

Proposition of mutual dependence: Mutual respect requires that both sides of an economic interaction not only pursue their own ends, but are also interested in enabling others to achieve their ends, i.e. "we make ourselves an end of others" and "through our will we make others our ends as well. The happiness of others is therefore an end that is also a duty." (Kant 1797, 6: 393.) This includes recognizing the dependence of future generations, and distant peoples, on us. This is so since our efforts affect them, and what we bequeath to them affects us.

This "interest" in enabling others essentially poses imperfect duty. If all sides of an environmental business interaction have an imperfect duty to be "interested in enabling others to achieve their ends," then these "others" must be broadly interpreted to incorporate all affected including the as-yet-unborn. (Possible trade-offs and compensation criteria associated with these imperfect duties are addressed in the penultimate section below.) As reviewed above, both perfect and imperfect duties logically stem from our respect for the dignity of persons, but are motivated by our pursuit of a moral community. This pursuit specifically begs the question of which community warrants our consideration. It is argued here that this community notion must be broad, and include all current and future humanity. Otherwise the "pursuit" violates Kant's third formula.

Being "interested in enabling others to pursue their ends," and knowing the effects of a particular business transaction on "their" pursuit of these ends, are separate and different concepts. The latter requires knowledgeable actions of an imperfect duty sort, i.e., to gather relevant knowledge, and perhaps once this knowledge is obtained, to take some particular actions. We have an imperfect duty to acquire knowledge about the potential effects of our actions, and once acquired, we may have either a perfect duty of action, or perhaps a further imperfect duty may be warranted. Since knowledge of the consequences of our actions or inactions is the basis of both perfect and imperfect, then the following proposition is suggested.

Proposition of imperfect duty to develop knowledge: We have an imperfect duty to develop knowledge about our potential obligations to others, as related to our actions or inactions. This includes knowledge concerning our environmental obligations and associated impacts.

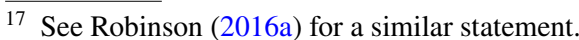

Two questions that are posed by the propositions above concern (i) whether the knowledge of the requirements of the intended receiver is passively obtained by the potential benefactors, or (ii) whether the knowledge developed by the benefactors is generated purposely through their own efforts? The former surely exists in that we might passively obtain knowledge about the needs of others by merely being acquainted with them, but the latter poses an imperfect duty of virtue (character) to actively seek the knowledge relevant to potential beneficiaries of our actions whether environmental or otherwise. ${ }^{18}$ In the wake of global warming and other severe environmental degradation problems, we consider most of the environmental knowledge relevant to our decisions to be scientific, i.e., business should be knowledgeable about its global environmental impacts as revealed by scientific analyses. There are, however, local impacts such as business' effects on local water drainage, or effects on local green-areas, or noise problems for which assembled knowledge ought to be required prior to any abatement or compensation considerations. The point is that there is an imperfect duty for acquiring relevant environmental knowledge, and because this is an imperfect duty, there are practical limits to this acquisition. How much information and analyses are required? What is the limit to the necessary degree of certainty that must be achieved to justify some action? Since one is not likely to know with certainty the ultimate impacts of many of business' decisions, can we risk severe environmental degradation? Business, either as a separate entity, or as part of an association, should develop the knowledge necessary to answer these questions and perhaps act accordingly. (See the exploration of this issue in the section entitled "Environmental Equity" below.)

Knowledge acquisition about its environmental impacts is a key imperfect duty for business. It is an imperfect duty because of the practical limits to this acquisition since all of business' resources could potentially be expended on this active effort. To a significant extent, it is reasoned social discourse that establishes these practical limits for business' environmental interactions, and this social debate requires appropriate knowledge in order to be relevant.

\section{Considerations of Specialness}

There are several attributes of the Kantian political CIP which we should consider as absolutely required for any notion of fairness to be applied to a system of moral maxims, especially as they apply to environmental considerations. (See Rawls 1958, 2001.) If the CIP represents the

\footnotetext{
18 Kant (1797, Chapter titled "On Duties to Others") refers to imperfect duties as those of virtue.
} 
commonplace way society believes our moral maxims should be formed, as Kant claimed, then we might be justified in attributing some high degree of specialness, or perhaps even sacredness, to the attributes of this process. ${ }^{19}$ These paramount, or sacred, attributes include the following:

- All those affected must have access to the social-democratic discourse required to establish our moral maxims.

- Rationality, that is the use of rational reflection concerning the moral issues at hand, is required to participate in this process of discourse. (See Wood 1999, pp. 306-309, for a review of Kantian reasoned discourse.)

According to Kant $(1785,4: 435-440,1793,6: 26)$, rationality is the defining characteristic of humans, a characteristic that makes life itself sacred. This is the attribute that must be applied to our environmental considerations as explored below.

Kant's first formula, the formula of universal law, prohibits us from behaving by personal maxims that are applicable only to us and that are designed only for our convenience. This also applies to business entities in its environmental considerations. Universality requires knowledge of and participation in our social discourse, but since future generations cannot be consulted, we must fairly consider and currently represent their interests when considering environmental impacts. In a similar way, Kant's formula for respect for the dignity of persons would also be violated by ignoring the interests of future generations. Providing the future with an environment that is limiting as compared to the current one would constitute ignoring the as-yet-unborn. It would force them to accept an inferior status within our considerations, and that violates our CIP. Our conundrum is "How do we include and represent their interests in our discourse?"

For one generation to decide the interests of another would appear to be paternalistic. O'Neill (1995, p. 120) defines paternalism as using others without awareness of their desired ends, but by imposing ends that we judge as should be desired by them. In the consideration at hand, paternalism appears unavoidable, so we must logically suppose what future generations will desire, perhaps doing so by projecting the similar preferences of the current onto the future, or perhaps by also referring to those desired by the previous generations in search for consistent values. If a current generation enjoys a particular set of environmental characteristics (clean water, air, and green spaces as

\footnotetext{
19 "Sacred" applies to more than religious considerations. It is commonly defined as "regarded with reverence," or "secured from infringement by reverence or sense of right." In this sense, the two Kantian attributes of the CIP cannot be infringed and therefore are "sacred" for these reasons as juxtaposed against religious "sacredness."
}

examples), then perhaps these are the minimums that should be bequeathed to the next generation. (These necessary minimums, however, may not be sufficient as explored in the next section where environmental restoration is considered.)

Kant argued that we seek a kingdom of ends, and by "kingdom," Kant meant "the union of different rational beings in a system by common laws" or maxims. (1785, 4: 433) Through the first two formulae, duties are derived and motivated by the pursuit of this kingdom of ends. The harmony, referred to in the third formula, means that these rational beings pursue consistent and coordinated duties aimed ultimately at pursuing this kingdom of ends. This applies to all individuals in this ideal union. Moral actions are therefore those that are motivated by the pursuit of this ultimate good. They cannot be those that serve only the self at the expense of others in this "union of rational beings." (1785, 4: 430) They cannot, therefore, knowingly exploit future generations. Indeed, in the Fundamental Principles of the Metaphysics of Morals (1785, 4: 390), Kant argued that examination of motivation is the only basis for judging the morality of some action, and pursuit of the moral community provides the only justifiable moral motivation..$^{20}$ Other possible motivations would be self-centered and selfish. Motivation to enhance the environment should not be self-centered, but it should broadly serve the pursuit of a moral community built upon the respect for the legitimate ends of all including those at distance and as-yet-unborn.

Given the religious and quasi-religious character of the environmental sentiments referred to above, the Kantian approach might appear to be strictly contradictory since being enlightenment philosophy, it is usually viewed as not amenable to religious considerations, even those that only bear "family resemblances" to religion. The argument presented below, however, explicitly addresses this dichotomy. It argues that to the extent that the public accepts the quasireligious logic concerning the sentiments generated by natural experiences, these sentiments should be reflected in the reasoned democratic discourse of the Kantian process as described below. Kant (1784a, 1793) only argued against the use of religious dogma for the purpose of exclusion of reasoned discourse.

I have emphasized the main point of enlightenment, that is of man's release from his self-incurred minority, primarily in matters of religion. (1784a, 8: 41)

Individual autonomy is not breached by reasoned non-dogmatic religious discourse. As a result, notions of the instrumental benefits to humanity of the sort outlined above would presumably be included in this reasoned discourse.

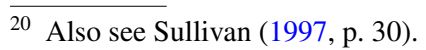


An ethical basis for the "specialness of nature" view typically utilizes either (i) the metaphysics of nature's sacredness (unique specialness) as a stand-alone entity, or (ii) the metaphysics of humanity's transcendent spiritual-type interconnectedness with nature, or (iii) a hybrid philosophy that combines the above two. ${ }^{21}$ Explorations of these approaches fit Saler's (1993) categorizations of "family resemblances" with traditional organized religion in that they use language similar to the religious canonical literature. (See Taylor 2017 , p. 248.) If the traditional religious experience is centered on "an uncanny, awesome, or powerful manifestation of reality, full of ultimate significance," as claimed by Chidester and Lilienthal (1995, "Introduction"), then interacting with nature also has this potential "significance," i.e., it is capable of offering an epiphany similar to those offered by traditional religious experience. ${ }^{22}$

As examples of this religious approach, Emerson (1836) and Thoreau (1854) provide early versions of the "transcendental inter-connectiveness" school. Concerning Thoreau's philosophy, Taylor (2017, p. 250, parentheses added) observed, "What everyone needs is direct, visceral and sensory contact with nature; this was his (Thoreau's) spiritual epistemology." An intimate relationship with nature was the essence of Emerson's and Thoreau's transcendental epistemology. ${ }^{23}$

Muir (1911) and Leopold (1949), however, both criticized anthropocentric theism-especially as initiated by Abrahamic religious extensions-as leading to nature's destruction. As emphasized by Leopold (1966, pp. xvii-xix),

Conservation is getting nowhere because it is incom-

patible with our Abrahamic concept of land. We abuse

land because we regard it as a commodity belonging

to us. When we see land as a community to which we

belong, we may begin to use it with love and respect.

Other religious sentiments, i.e., those that honor nature as independent of our dominance, are emphasized in Native American beliefs. (See La Duke 1999.) Muir (1911), however, emphasized natural preservation for the purpose of human interaction and termed its destruction as evil. (See Taylor 2017, p. 252.) Muir pointed out that today "we go to

\footnotetext{
${ }^{21}$ Schuler et al. (2017, p. 216) identify the second of these arguments (humanity's transcendent connectedness) as necessarily utilitarian. This is not the position developed below where a Kantian approach is presented.

${ }^{22}$ Wood (1998, pp. 192-204) argues that nature is a teleological system that serves humanity so that its preservation is a perfect duty as described below. O'Neill (1998) reinforces notions of this teleological perfect duty.

23 Thoreau $(1849,1862)$ offers additional explorations of the benefits of transcendental interactions with nature.
}

the woods" as a substitute for churches and temples. (See Burroughs 2009, p. 246.)

These philosophies contain a foundational motivation aimed at providing the metaphysical grounding for valuing nature either as sacred in itself or as sacred due to its spiritual contributions to humanity. (This latter argument is presented below.) If there is no spiritual basis for natural preservation or enhancement, "then one could argue that any valuing of nature expresses mere emotion. ... without some sort of sacred ground for this (natural) experience, the accompanying feelings and values are at best transient, and at worst delusional." (Taylor 2017, pp. 256-257, parenthesis added) In reviewing the Kantian analysis below, we should recognize the concept of a natural sacredness, or perhaps a sort of unique specialness, as instrumental to the human experience. This claim is justified by the substantial literature that supports this traditional view. The important point is that the Kantian reasoned-discourse approach has the ability to reflect this instrumental spiritual role of nature if this is society's reasoned view. This is emphasized in the following section. This Kantian environmental philosophy is essentially "the other side of the coin" from the sacredness or specialness of nature argument; if nature is special, it is because of its special instrumentality to humanity.

\section{Environmental Equity}

In the Kantian ethical system, society's regulations should apply as perfect duties assuming the CIP is followed in their formation. This assumes a high degree of reasoned social discussion that is open to all. Rawls $(1958,2001)$ reviewed the Kantian requirements necessary to assert that society's regulations are fair, but Rawls' analysis did not directly consider environmental issues, especially those involving intergenerational equity, and fairness to people at distance. ${ }^{24}$ This consideration is addressed below, however, by applying Rawls' broad philosophical principles.

In this section, Rawlsian criteria for considered moral judgments are applied to environmental decisions of both public policy and business' involvement in the formation of these policies. These objective criteria assist in clarifying the nature of "reasoning" in reasoned public discourse, particularly concerning the problems of intergenerational equity and people at a distance. Prior to analyzing and applying these criteria, however, reviews of these two related problems (the intergenerational and distant people problems) should be presented.

\footnotetext{
${ }^{24}$ Rawls analysis primarily considered distributional issues and not environmental issues.
} 


\section{The Intergenerational Problem}

Rawls (1987) argued that any social conception of justice derived by the CIP should be sufficiently acceptable to the populace as to be stable from one generation to another, i.e., it should be built upon those lasting moral foundations that are acceptable to overlapping generations. With respect to these moral foundations, Rawls (1987, p. 427) states,

They are both general and comprehensive moral doctrines: general in that they apply to a wide range of subjects, and comprehensive in that they include conceptions of what is of value in human life, ideals of personal virtue and character that are to inform our thought and conduct as a whole. Here I have in mind Kant's ideal of autonomy and his connecting it with the values of the Enlightenment.

This notion of autonomy, as applied to the problem at hand, must counter any paternalism toward the needs of the future or for those at distance. Their environmental needs should not be considered inferior to our own. In addition, this social conception of justice must form "a fund of implicitly shared fundamental ideals and principles." (Ibid, p. 427) Such a conception might then be seen as "a fair system of social cooperation." (Ibid, p. 428) "General and comprehensive moral doctrines" reached by reasoned social discourse are likely acceptable to each cohort of overlapping generations since logical analysis is easily communicated as compared to emotional declarations. This is true because emotional appeals are based on the current fashions of the sort that are time dependent to the particular age. The history of philosophy, however, illustrates logical arguments that have lasted centuries. Rational arguments are likely to be longer lasting than emotional ones. One problem posed, however, is that these fundamental ideals must include "certain guidelines of inquiry and publicly recognized rules of assessing evidence to govern applications." (Ibid, p. 429) This notion also robustly applies to environmental inquiry and judgment, especially with respect to intergenerational judgments as explored below.

The issue of "shared fundamental ideals" presumably includes Kantian notions of "everyone" as expressed in the CI. (This assumes Kant's notion that the CI expresses the common sentiments of the populace.) This must assume consideration of fairness for both future generations and people of distant lands. The "general and comprehensive moral doctrines reached by reasoned discourse," and agreement with respect to the scientific evidence relevant to judgments concerning environmental catastrophe, along with the resulting appropriate decision criteria, may be difficult to achieve within one generation let alone for overlapping generations. Current evidence of this difficulty abounds, as illustrated below.
Consider that current (2017) EPA Administrator Scott Pruitt initiated a rollback of more than 30 recently established environmental rules that he claimed stymied business development. These rollbacks include the following:

- a weakening of the Obama Administration's Clean Power Plan,

- a weakening of established rules for curbing pollution in US waterways,

- a weakening of established regulations to restrict leaks of methane associated with fossil-fuel extractions,

- a weakening of established regulations of chemical plants aimed at preventing spills and explosions,

- a weakening of established regulation of pesticides linked to damage of children's nervous systems, and

- a withdrawal from the 196-nation Paris Agreement on Climate Change. ${ }^{25}$

Davenport (2017, p. A4) indicates that these regulatory rollbacks were without consultation with EPA's extensive staff of scientists, but were composed after extensive consultation with industry lawyers and lobbyists, and also after $\$ 4.2$ million in political contributions expended from energy-related business. The relevant question is "Were these rollbacks considered judgments in light of a public consensus concerning (1) the appropriate data to be considered, and (2) the appropriate decision criteria to apply?"26 (Note that the definition of a considered judgment is presented in the next section.)

Between generations an overlapping consensus must be formed with respect to what one generation owes the next, i.e., the degree of environmental degradation, preservation, or enhancement desired, allowed, and owed. The UPJ referred to above applies to this intergenerational conundrum in that the freedoms of future generations are affected when we make current environmental choices. If we treat the next generation cavalierly, without regard to the quality of its future, without reasonableness or fairness, then it will likely treat the following generation similarly. The environment will collapse from human destruction. To achieve the opposite requires the use of "full public reason," according to Rawls. (Ibid, p. 442) "Full public reason" requires that logical public discourse and debate utilize the relevant

\footnotetext{
${ }^{25}$ On January 5, 2018, the Trump Administration also announced a rollback of restrictions on petroleum drilling in almost all offshore areas of the USA.

26 The rollbacks concerning methane gas emissions were overturned by a D.C. Circuit Appeals Court that found that Administrator Pruitt had not followed the "public notice and comments solicitation" requirements under the Administrative Procedure Act of 1946. See Bravin (2017, p. A4). If this decision is accurate, then the public's discourse opportunity was truncated.
} 
scientific knowledge as to future environments. This is the focus of Kantian environmental discourse. It should also be noted, however, that one generation might decide that it was unfairly deprived of some environmental resources, and seek its restoration or enhancement, and as a result it bequeaths its conception of a better world to the next generation.

In Kantian analysis, the pursuit of the moral community must not be generated from egoistic consequentialist motives in that the third formula of the CI provides the moral motive for actions of volition. In keeping with this notion, one generation must consider the impacts on future generations. The third formula does appear, however, to be linked to communitarian motives, especially as expressed by de Shalit (1995) in the environmental context and reviewed by Nolt (2017). Identifying with a community in pursuit of environmental initiatives inclusive of the future may provide a vision of oneself as a moral crusader along with a community of others who are similarly moral. This potentially provides a "friendship of virtue" reinforcement as in Aristotle's Nicomachean Ethics. ${ }^{27}$ As such, it yields positive psychic benefits, but these psychic benefits are ancillary to the Kantian motive, and not the basis of the motive. If it were otherwise, the motive would likely be weak and unreliable.

\section{The Problem of Equity for Distant People}

As with the intergenerational problem, providing environmental equity for people at distance requires general inclusive agreements as to the relevant information to be considered, and the appropriate decision criteria. These are specific problems logically analyzed in the next section. Global warming is the environmental conundrum of our age, and it applies to both intergenerational problems and the problem of providing equity to those at a distance. Distant people cannot equally participate in our own social discourse, at least not without significant effort. The Paris Climate Accord, however, organized by the United Nations Framework Convention on Climate Change (UNFCCC) includes 196 signatories from five continents. The Accord was signed on December 12, 2015. This illustrated the possibilities of overcoming the problems of distance.

The Accord seeks to limit greenhouse gas via having each signatory nation pursue its own goals through both expansion of clean renewable energy sources and energy efficiencies, both of which are business problems of great importance. For example, as part of the Accord France plans to ban all petrol and diesel vehicles by 2040 and to discontinue coal production after 2022. Technical experts are to monitor progress with each signatory agreeing to transparency with

\footnotetext{
$\overline{27}$ See Robinson (2016b) and Cooper (1980), for reviews of this dynamic reinforcement.
}

respect to this monitoring. The ultimate stated goal is to limit average global temperature increases to a maximum of two degrees centigrade as compared to preindustrial revolution temperatures. The agreement does allow for carbon trading between countries to enable reaching their goals. ${ }^{28}$

The Paris Accord is an extension of the Kyoto Protocol of 1997, which was itself extended by the Doha Amendment of 2012. The former Protocol limited greenhouse gases between 2008 and 2012; the latter extended these limitations to 2015 when the Paris agreement came into effect.

These agreements culminated a lengthy process of negotiation among almost 200 countries, but in June 2017, the Trump Administration indicated that it intends to withdraw from the Accord. The earliest possible date for withdrawal is November 4, 2020. This withdrawal appears to be an example of a hard won but abandoned agreement among peoples at great distances, an accord that addresses the most significant environmental issue of our age.

The section below reviews Rawlsian criteria for considered moral judgments, and these criteria include requiring decisions to be informed and stable across competent moral judges. It is argued that these criteria are relevant to our recent environmental decisions such as those illustrated above.

\section{Considered Moral Environmental Judgments}

The environmental problems of intergenerational equity and people at a distance concern those to be included in social discourse, and the logic of the arguments included. They especially concern the decision criteria, and the information necessary to reach environmental decisions. The Rawlsian criteria reviewed below assist in analyzing these moral problems, particularly in perceiving business' obligations that result from this reasoned discourse.

Rawls (1951, p. 1) posed the relevant question for our analysis, "Does there exist a reasonable method for validating and invalidating given or proposed moral rules, and those decisions made on the basis of them?" Rawls' purpose was to discern rules centered on inductive logic. He attempted to do so by elucidating two categories: competent moral judges and considered moral judgments. He used the former as one condition for the latter. ${ }^{29}$ We can apply the latter to discern the rationality of our decisions, but this

\footnotetext{
${ }^{28}$ The U.S. National Climate Assessment, a consensus report of scientists at US agencies and peer-reviewed by the National Academy of Sciences, recognizes global warming and assigns the causation to greenhouse gas.

${ }^{29}$ Note that in this analysis, Rawls essentially differentiates a virtue ethics approach (the criteria required to be a moral judge) from a deontology approach (the ex post criteria for a moral decision).
} 
requires the former for defining what is termed the "stability criteria," as explained below.

Rawls' competent moral judges manifests four characteristics.

1. They have a requisite degree of intelligence required for analysis of the issues at hand.

2. They desire to be knowledgeable concerning the facts relevant for the analysis.

3. They have a predilection to use reason, i.e., they are open-minded, they use inductive logic, and they are knowledgeable about their own potential biases. This includes not applying a prior ideology to the analysis of the facts at hand.

4. They have the capacity and desire to consider all interests relevant to the considerations at hand.

A predilection to exercise these four characteristics constitutes what Rawls terms intellectual virtue. (Ibid, p. 5) With respect to environmental concerns, we ask whether those engaged in the current environmental policy debate seek the relevant scientific knowledge, and whether they are open-minded and logical in their decisions or merely ideological? For example, with regard to our specific illustrations above, we could ask, "Was EPA Administrator Pruitt open minded and knowledgeable in ignoring the work of EPA scientists?" Did he have a predisposition to consider all relevant information without ideological bias? To answer these questions we should consider the above Rawlsian criteria.

In addition to characterizing the criteria for competent moral judges, Rawls also characterizes considered moral judgments as manifesting four characteristics.

1. The judge is disinterested, i.e., cannot benefit or be affected by the judgment (no conflict of interest).

2. The judge is familiar with the relevant facts.

3. All those affected have opportunities to present their arguments.

4. The judgment is stable across decisions by other competent moral judges.

These criteria can be applied ex post to judge whether a particular decision is a reasoned one. For example, were the decisions of Administrator Pruitt to overturn the regulations cited above informed. If not, then Pruitt's judgments might not fit the category of stable under other moral judges. With respect to this fourth condition, individual predilections may be counteracted when many judgments are made in a wide variety of roughly similar cases. The reasonableness of decision criteria can be decided by the acceptance of those competent moral judges who have freely weighed the evidence after open discussion and criticism. This provides evidence that it can "hold its own." These criteria can be applied to our society's environmental decisions. For example, are these decisions made by those with conflicts of interests, or were the relevant facts rationally considered rather than made on an ad hoc basis and out of step with logical analysis. (Some examples of unreasonable decisions are presented below.)

These criteria for competent moral judges and considered moral judgments can be used to evaluate the reasonableness of the intergenerational environmental decisions, as well as those addressing the effects of people at a distance. For example, conflicts of interests, and a prior ideology that interferes with either information gathering or evaluation of data, both bias the objectivity of those decisions. In addition, it is apparent that being a moral judge does not necessarily result in a moral judgment in that violations of the criteria above might not pass the reasonableness test. These criteria, however, may appear to apply only to individuals and not for the overall societal decisions, but if a plurality of the unbiased and informed establishes environmental policy, then the reasonable criteria apply to the results of our social discourse. Open and informed democratic discussion may be expected to result in considered moral decisions with respect to the environment and associated intergenerational problems, but this might not always result. The Rawlsian criteria assist in discerning those that do not. As reviewed above, individuals, and business people in particular, have imperfect duties to be both informed and unbiased concerning these matters, criteria specified for both moral judges and considered judgments, but the public must also be wary of influences from those with conflict of interest in exploiting the environment as reviewed in the next section.

There is, however, one criterion for being a competent moral judge that might be easily overlooked in this analysis. The criterion of having a predilection to use inductive logic, especially to envision potential impacts of our decisions, and the information necessary to assist in this envisioning, should be emphasized as necessary for aiding our environmental discourse. For example, people in general, and perhaps particularly business people since they are already involved in the cooperative ventures we call business, should have the capacity and inclination to envision the degree of "environmental good" achievable through cooperative endeavors. (Examples are presented below.) Along with this, they also should have the capacity and inclination to participate in the pursuit of environmentally conscious actions, and through this participation, they might develop community trust that perhaps leads to further actions, and further reinforcement. These actions may lead to overcoming the tragedy-of-the-commons phenomena, but for these to occur, certain biases must be overcome as indicated below, biases that would disrupt logical analysis. The notion of pursuing an inclusive moral community, one that addresses intergenerational environmental concerns, is possible, but 
as stated above, "certain guidelines of inquiry and publicly recognized rules of assessing evidence" must be understood and followed. The biases reviewed should be considered in the context of the Rawlsian criteria for moral judges and considered judgments specified above. The critical barriers to reaching any possible consensus among overlapping generations, barriers that potentially prevent the full public reason required of a rational Kantian "focus" on environmental issues, consist of these biases and violations of the Rawlsian criteria.

\section{Anthropology of Environmental Rationality}

Kant (1797, 6: 458-459, and 6: 465-469) combined his ideal norm of the rational discourse of the CIP with the anthropological observations of humanity's antisocial biases. ${ }^{30}$ The CIP ideal potentially could overcome these biases at least in part. In this Kantian spirit, and in the context of environmental problems, some irrational biases that would interfere with the ideal of rational social discourse are explored here. The previous section explored the possibilities for informed and unbiased environmental decisions, what Rawls termed considered moral judgments. These biases contradict the criteria for considered judgment.

\section{Irrational Biases}

\section{Cooperation Versus Autonomy and the Information Problem}

Business exists in a world of limited resources; there are costs and possible benefits resulting from its decisions, and these costs and benefits include externalities. One principle externality results from the inhibitions against cooperative action and in favor of atomistic competition. ${ }^{31}$ Consider, for example, the tragedy of the commons as illustrated by a fishery; any particular fishery, perhaps the Grand Banks cod-fishery as an example. This resource could be completely eliminated through overfishing. At some point, the fish stock could reach levels below the critical level needed for a positive net-reproductive rate, and the fishery would

\footnotetext{
30 Kant's stated biases include "arrogance, defamation, ridicule, envy, ingratitude, malice, and desire for revenge." Also see (1784b, 8: 21) for Kant's analysis of people's tendency to "isolate" themselves rather than join cooperative endeavors.

31 This bias for atomistic competition and against cooperative action can be an expression against giving up control associated with the latter and in favor of the individual entrepreneurial independence of the former. See Kant (1784b, 8: 21) for a review of the tendency toward isolation.
}

then completely collapse. ${ }^{32}$ If the individual fishermen know this is occurring, and they believe that if they do not harvest cod, others will so they may as well harvest, then overfishing will continue beyond the critical mass level. For this destruction to occur, any one of three conditions might be causal assuming fishermen believe that the continuance of the fishery is desirable:

1. The fishermen are either not knowledgeable, or perhaps are in willful denial, about the effects of overfishing.

2. The possibility of reaching a cooperative agreement to limit harvests is considered remote, when perhaps it is not.

3. The discovery of the potential fishery collapse comes too late to save the fishery.

In the third case, there is a timely knowledge problem, one that can be potentially solved through collective scientific action based upon information about the stock levels. Knowledge about optimal harvests is a business problem, and in these tragedy-of-the-commons cases, a solution generally requires collective action and cooperation. That is the rational business solution, but knowledge about the willingness of other fishermen to join a cooperative may be lacking. If it is known that others are willing to join, then it is more likely that each individual fisherman will also be willing to join. The criteria for a competent moral judge include a "desire to be knowledgeable," and the criteria for a considered moral judgment include "familiarity with the relevant facts." This example illustrates one of many cases of the moral obligation of business to be rational and informed with respect to environmental concerns, one associated with cooperative action, but a lack of familiarity with the relevant facts stimulates a failure of this cooperation under the first two conditions listed above. ${ }^{33}$ This points out the linkage between the imperfect duty to develop relevant knowledge (the proposition of imperfect duty to develop knowledge), and obtaining solutions to environmental problems.

Besides the possible knowledge problem illustrated above, there are four other destructive biases in the conduct of business associated with environmental problems, biases that are caused by conflicts of interest, lack of open

\footnotetext{
32 For a history of this actual phenomenon involving the Grand Banks see Murawski (2017).

33 Clark's (1976, Chapters 1-2) exploration of the fisheries problem demonstrates an application of rational economic analysis to finding an optimal fish stock, and this example is worth keeping in mind as demonstrating "rationality." In this solution, the "optimal" stock exceeds that necessary for "maximum sustainable yields" in that higher stocks lower the costs of harvesting, and perhaps also decreases some other external costs as well. See also Bjorndal and Munro (2012) for reviews of the rational management of fisheries around the world.
} 
consideration, and other violations of the criteria for considered moral judgments as presented above and illustrated below. Avoidance of these biases is necessary to provide some logical rationality to environmental analyses, a rationality demanded of reasoned social discourse of the Kantian framework. These destructive biases are reviewed here.

\section{The Bias Caused by Abundance}

If some environmental resource is so abundant that we consider the cost of exploitation (harvesting) to be very low, then rational lower-cost alternatives (lower total costs to society after externalities are considered) are less likely to be explored. This will probably continue to be the case until a high degree of scarcity occurs. This is so because the initial social costs of developing alternatives, as broadly defined to include the external costs, will be higher than current narrowly measured exploitation costs actually paid by business. ${ }^{34}$ Incorporating the effects of externalities, however, especially the externalities imposed upon future generations, may remedy this bias. Scarcity typically causes higher costs for exploitation and involves possible future deprivation of the goods in question. Pricing the possible future scarcity so that later generations are considered is justified from the rational Kantian view. This requires our rational public discourse to consider future scarcities and adjust public environmental policies accordingly, i.e., restrictions on the use of the resource to levels that reflect the external costs imposed on society. A reasoned public discourse that is expected to lead to an unbiased public environmental policy must express and reflect familiarity with relevant facts of potential future scarcity.

For example, consider harvesting old-growth timber in the rain forests of the US Pacific Northwest where this timber is likely found on steeply sloped higher-elevation mountainous terrain. (See Oregon Wild 2017a, b.) Preserving the old growth likely preserves the watershed below in that if the timber is harvested, the soils are easily and quickly washed away down the steep slopes so that with the top soil eroded, replanting is difficult and unlikely. The soil erosion, moreover, clogs streams and destroys their flow, and ruins fish-spawning beds. The future is deprived of the natural watershed, plus the sight and recreational values of the slopes, streams, and the fishery. This illustrates that current abundance does not necessarily mean that the resource is relatively inexpensive to harvest, not when future external effects are considered. A lack of these information considerations violates the Rawlsian criteria for a considered moral judgment.

\footnotetext{
${ }_{34}$ Note that "broadly defined" requires incorporating the costs of those disrupted due to having to change, plus any externality costs.
}

\section{The Bias Due to an Overly Narrow Vision}

As illustrated by the timber-harvest problem reviewed above, an "overly narrow vision" leads to bias toward current natural-resource exploitation when perhaps it would be rational to preserve the resource. For example, consider not envisioning the possible value of recreational use of hiking through old-growth forests, or not envisioning substitutes for the timber that would be harvested, substitutes such as particle board, or substitutes other than wood. ${ }^{35}$ This fits the description of "too narrow a vision," but this also begs the question, "Who does the envisioning?"

The answer to the "envisioning" problem could be that business should be searching to develop substitutes, but this search might be truncated by too-narrow a vision. Once substitutes are posed, society may decide, "It is preferable to preserve an old-growth forest, and use a substitute!" The point is that business, with sufficient expertise, can pose alternatives to environmental exploitation and degradation. Business can lead society into broadening its vision for resource use so that alternatives can protect the environment. Examples of business providing these alternatives are so numerous that publication space prevents a lengthy listing, but consider a partial listing of (1) development of environmentally safe insecticide and detergents, (2) grocerychain provision of reusable shopping bags as substitutes for disposable plastic bags, (3) improvements in auto and truck emissions, and (4) the increase in renewable energy projects. Business potentially can help the public to satisfy the information criteria for a considered moral judgment by overcoming "overly narrow vision."

\section{The Bias Due to "It's Gone!"}

"Out of sight, out of mind!" "When its gone, its gone!" These adages may apply to those environmental resources that are either completely eliminated or so degraded as to not be recognizable as an environmental asset; yet like the steelhead runs that are completely eliminated by gillnetting, they can be restored through proper management although at sizable public expense. (For an example of this gillnettingproblem phenomenon, see https://www.youtube.com/watch ?v=KmZ1ScAUxA0.)

Rivers and watersheds provide numerous examples of tragedy-of-the-commons phenomena, but they also provide numerous examples of citizen-business coalitions working

\footnotetext{
35 Schuler et al. (2017, p. 215) argue that finding "substitutes takes work and time" that cannot be justified to shareholders. This position is overly pessimistic; the record of finding substitutes does not justify this pessimism. Research and development certainly may require investment of resources, but it is the development method business routinely uses.
} 
to restore water-based resources. These water resources have often been severely degraded, but restoration coalitions, such as those of the Riverkeepers Associations, have organized to regenerate virtually every significant river in the USA. The regeneration consists of (1) restoration of the ecology of riverbanks and drainage basins, (2) establishing and enforcing pollution-prevention laws, and (3) monitoring of environmentally safe development of river usage.

Consider the Ipswich River as an example. It was in the past a picturesque trout stream in Northeastern Massachusetts. The river feeds a marshy coastal area that was once of considerable beauty. Sixty years previously it was an environmental asset; it was a meandering trout stream that added considerable sight value to those areas it flowed through, and it also provided a valuable shell-fish resource, a saltwater fish resource, and tourist attraction. Today it is largely a filled-in quagmire destroyed by real estate development, both home dwellings and commercial enterprises, although this degradation decreased the area's land values below what they otherwise would be. The Ipswich River Basin now is an example of the tragedy-of-the-commons phenomena. It occurred despite legal prohibitions as to destruction of the drainage and alteration of the river route, legal prohibitions that were ignored by the local governments responsible for their enforcement. Currently, however, the Ipswich River Watershed Association is attempting restoration by purchasing land along the river's route to protect the ecology of the watershed, by controlling the polluting suburban water run-off, by restoring tributary drainage, and by restoring the legal river banks that have been filled in. ${ }^{36}$ The abovementioned Watershed Association is a coalition of business, private, and government interests as suggested below.

These environmental degradations would likely not have occurred if (i) participants had the necessary information to anticipate the ultimate effects of their isolated actions, (ii) all those who would be negatively affected were knowledgeable about these facts and were given the opportunity to participate in the public discourse and decision making, and (iii) actions that degraded the environment, thereby imposing external costs on others, were prohibited. The first two of these fit the Rawlsian criteria for violations of considered moral judgments.

Other rivers in Massachusetts, such as the Charles, Deerfield, Concord, and Shawsheen Rivers as examples, also have public restoration efforts to clean up considerable pollution. Environmental restoration is possible if the bias of "Its gone!" is overcome. Rivers such as the Merrimack, a significant New Hampshire and Massachusetts river, have restored fish runs by eliminating dams and by restoring water quality. Unlike prior to these efforts, the Merrimack

$\overline{36}$ See www.ipswichriver.org. is now worthy of substantial non-polluting public usage. ${ }^{37}$ Its restoration depended on satisfying the criteria of considered moral judgments in so far as including the knowledge relevant to envision the impacts of improvements.

\section{The Bias of Not Having "Broad Vision"}

Each of the above bias categories is a subset of "not having a broad vision." There may be other biases, but essentially an unbiased vision of sustainability and environmental restoration and/or enhancement can motivate rational decisions. The environment is humanity's home. It provides sustenance necessary for life. It also provides the spiritual connections referred to in the special considerations section above. Destroying it dims humanity's future and degrades lifestyle and enjoyment. This is irrational! Business bears much of the blame for environmental degradation, but enhancing humanity's home and lifestyle is potentially also an essential business task, one demanded by society. Past profiteering from negative externalities might be corrected by actions that generate positive externalities. ${ }^{38}$ This poses opportunities for business people who have a proper "broad vision." Business is a cooperative endeavor, and so is environmental enhancement. In addition, personal consumption need not cause environmental degradation; it can consist of nondegrading environmental enjoyment, and this can stimulate further efforts toward environmental enhancement.

It is natural for business to acquire knowledge related to its current and potential future activities. It is natural, therefore, for business to apply this knowledge for the environmental tasks indicated above. If we consider the Ipswich River example reviewed above, the Ipswich clams that come from the marshy beds of its delta are a highly prized resource of considerable value. ${ }^{39}$ Knowing this, some businesses seek to harvest this renewable resource. They promote the Ipswich River Watershed Association (a public-business coalition), its activities, and the sustainability and restoration of this resource.

In Kantian analysis, it is rational discourse that is of paramount importance, and this includes the discourse necessary for the public's rational environmental considerations. The biases reviewed above interfere with this rationality. They

\footnotetext{
37 See www.combat-fishing.com/massstipersmerrimackrvr.html for a review of striped bass restoration in the Merrimack, and www.conco rdmonitor.com/fish-stocking-2127105 for a review of restoration of herring in the river.

38 For example, promotion of environmental recreation via commercial means might generate the sort of public enjoyment that leads to further restoration.

39 See www.ipswichfishmarket.com/clams.aspx for an example of business involvement in restoration of this resource, and www.saveu r.com/article/Kitchen/Ipswich-Clams for a review of this delicacy.
} 
should ultimately be identified as such in public discourse pertaining to environmental policy, and they can be modified through business-generated information. The public's environmental decisions should be capable of being classified as considered moral judgments.

\section{Business Knowledge, Compensation, and Conflicts of Interest}

The above section indicates that there is a role for business knowledge that is either passively acquired through providing the public with goods and services or that could be acquired through the search for new opportunities. The public sector also acquires knowledge with respect to its environmental concerns. Businesses, however, have natural conflicts of interest with respect to environmental exploitation, namely business may be able to profit through developing negative externalities associated with environmental exploitation, i.e., dumping costly by-products on the environment thereby externalizing them. Classical cases of these exploitations involve water, air, and various poison-type pollutions associated with industrial, agricultural, and suburban development.

Using rivers and streams as sewers for business-generated pollutants, such as the textile industry's dumping of industrial chemicals into the Chattahoochee River of North Georgia as an example, or air pollutants from pulp mills as another example, has long histories going back to the origins of the industrial revolution in the USA. (See Thoreau 1849 , for observations of early industrial revolution river pollution on the Concord and Merrimack Rivers. Also, see https://chattahoochee.org/water-quality/ for a review of the textile industry's pollution of the Chattahoochee River.) Developing landfills with chemical pollutants from business, such as Love Canal in Western NY, provides other examples. (For a review of the Love Canal environmental tragedy, see https://archive.epa.gov/epa/aboutepa/love-canal -tragedy.html.) The point is that business has historically had conflicts of interest when involved with formation of the public's environmental policy. These conflicts of interest imply that business' input must be considered by the public as biased in its discourse efforts, but this does not imply that when business acts within the constraints of those fairly established public policies, it cannot contribute to environmental enhancement. (See Rawls 1951, 2001, for an analysis of the ethics of conflicts of interest and the notion of fairness in this association.) Business overall may be destructive in its biased influence on public environmental policy, but this does not imply that individual businesses cannot positively affect environmental enhancement through its efforts. ${ }^{40}$

The Nobel Laureate Ronald Coase contributed strongly to the literature and considerations of negative environmental externalities. ${ }^{41}$ One of his contributions is the Coase theorem presented below. This has been used to argue that negative environmental externalities are not as severe a public problem as usually cited.

The Coase theorem: (1) under conditions of welldefined property rights, and (2) in the absence of transactions costs associated with negotiations over property rights, it may be socially efficient for those who exploit environmental resources to continue doing so provided they can sufficiently compensate those who suffer the negative externalities. ${ }^{42}$ The market can therefore be efficient even in the presence of negative externalities.

One problem with the Coase theorem, and its theoretical compensation, is that we most often do not have welldefined property rights with respect to public resources such as breathable air or clean water. The public typically does not have the right to sell the quality of air or water to private interests. In addition, the incentives to exploit these resources via pollution also stimulate public corruption associated with the legalities necessary to control negative externalities, such as illustrated by the Ipswich River degradation cited above. The tragedy-of-the-commons phenomena concern public resources and their destruction, and not the destruction of private property rights. These public resources also have considerable positive externalities, as with the old-growth forest and watershed examples used above, and without public management that is not corrupted by business, these positive externalities will also be destroyed. Compensation for these externalities is seldom feasible.

With respect to degrading the environment of future generations, can we compensate for this degradation via provision of some other good, perhaps technological advances as an example? A public decision to degrade a future environment in exchange for some other non-environmental provision would be purposely paternalistic, as defined above, and this would be anti-Kantian. In this situation, the current generation would decide the compensation for the future generation. "We will take your environment, but as compensation, we will give you this technology that we like!"

\footnotetext{
${ }^{40}$ Cohen and Dienhart (2012, pp. 96-100) consider the moral problem of business' influences on law formation as a type of corruption.

41 Coase won the Nobel Prize in Economics in 1991.

42 By socially efficient, we mean from the standpoint of welfare economics.
} 
This is clearly paternalistic in its presumption and would not occur if current public discourse ethically incorporates the interests of future generations.

\section{The Kantian Foundation}

It is argued above that the Kantian foundation for environmental maxims as they apply to business is built upon the notion of a reasoned social discourse. This discourse is itself centered upon the imperfect duty to acquire relevant knowledge. Current environmental business problems largely concern the control of negative externalities associated with commerce, and also the generation of positive externalities gleaned from public-business coalitions essential for environmental restoration and for prevention of further tragedy-of-the-commons devastations. All of these require scientific information to reach considered moral judgments, a Rawlsian term with specific applicable criteria explored above. This Rawlsian set of criteria is shown to be relevant to solving the environmental problems associated with intergenerational equity as well as people at distance, both of which are central moral problems for our reasoned debate.

Rational public discourse must also generate agreements as to both the necessary information and the relevant decision criteria required to resolve both the intergeneration and people at a distance equity issues. In exploring the necessary information required of reasoned discourse, this article reviews a variety of biases in information gathering and evaluation that potentially inhibit these agreements. It is pointed out that in this context, business expertise can offer unbiased information-based solutions particularly with respect to coalitions that might resolve tragedy-of-thecommons problems. Some examples of these coalitions are offered, as well as examples of the biases they might overcome. In this way, rational public discourse may resolve the problems associated with an insufficiently broad vision as to the methods and benefits of preservation and restoration. Examples are provided that illustrate the notions of "broad vision" in the context of environmental problems.

One discourse inhibition, explored above, results from assertions of a quasi-religious dogma with respect to nature. These dogmatic assertions likely interrupt reasoned discourse. Perhaps a moral philosophy based on a vision of nature as completely independent of human considerations is an appropriate foundation for motivating the resolution to the severe environmental crises of our age. Such a vision of nature as independently sacred, however, resembles a traditional religious approach, and as a result, it elicits problems associated with reaching a consensus. Perhaps some minority might accept a nature-based religion, but others see nature as strictly instrumental to humanity. The instrumental approach either recognizes that environmental preservation is biologically necessary for a sustained human future, or that transcendent spiritual-type interaction with nature is a necessary or paramount human experience. The benefits of nature as instrumental to humanity are likely incorporated and reflected in reasoned social debate, and perhaps these instrumental arguments are persuasive. A coalition consensus might be reached among these heterogeneous groups (nature as instrumental and nature as independently sacred groups), but agreement must still be reached as to the evidence to be considered, and also the decision criteria to be used concerning environmental preservation and restoration. Kantian rational discourse, as explored above, particularly applies to these problems.

Perhaps the Kantian approach to reasoned discourse only poses an ideal, but this is an ideal worthy of understanding and pursuit. It provides clarity as to our social failings and their origins, including our environmental failings. This is the advantage of this analysis. The Kantian categorical imperative process for forming these maxims requires (1) duty motivated by pursuit of a moral community, and (2) a reasoned social discourse that includes considerations of both future generations and distant people within this conception of community. The second of these requirements poses a conundrum, namely since future generations and distant people cannot be included within the social discourse required for establishing our ethical maxims, then rationality requires that we represent and preserve their interests. This poses the potential problem of paternalism. The only resolution is that this "rationality" requires generally accepted ethical standards for acquiring the relevant knowledge and establishing the associated decision criteria as related to business, standards that are stable across generations, and that bequeath a preserved and perhaps restored environment.

Business knowledge and expertise may be necessary for reasoned social discourse concerning environmental preservation, but the conflicts of interests inherent in business' profit exploitation through negative environmental externalities, a common phenomenon observed since the early industrial revolution, imply a limited role for business. When participating in this discourse, business must be perceived by the public as having potential conflicts of interest according to the Rawlsian criteria for a competent moral judge. Business expertise, however, can still be an asset too valuable to ignore. In this context, business has an imperfect duty to play a role in environmental enhancement coalitions and to provide relevant scientific-based information for public consideration of their environmental impacts. This is an imperfect duty, however, since there are practical limits to its coalition involvements. In particular, business has an imperfect duty to participate in coalitions aimed at resolving tragedy-of-the-commons phenomena. This is therefore a part of the Kantian rational foundation for business-environmental policy discourse. 
Funding This study was entirely unfunded by any grant or other source.

\section{Compliance with Ethical Standards}

Ethical Approval This article does not contain the results of any studies with human participants or animals performed by any author.

Open Access This article is distributed under the terms of the Creative Commons Attribution 4.0 International License (http://creativeco mmons.org/licenses/by/4.0/), which permits unrestricted use, distribution, and reproduction in any medium, provided you give appropriate credit to the original author(s) and the source, provide a link to the Creative Commons license, and indicate if changes were made.

\section{References}

Bjorndal, T., \& Munro, G. (2012). The economics and management of world fisheries. New York, NY: Oxford University Press.

Bravin, J. (2017). EPA Push on Emissions Standards Blocked. Wall Street Journal, p. A4, Wednesday, July 5, 2017.

Burroughs, J. (1912, 2009). Time and change. Amsterdam: Fredonia Books.

Chidester, D., \& Lilenthal, D. (1995). Introduction. In D. Chidester \& D. Lilenthal (Eds.), American sacred space. Bloomington, IN: Indiana University Press.

Clark, C. (1976). Mathematical bioeconomics: The optimal management of renewable resources. New York, NY: Wiley.

Cohen, M. A., \& Dienhart, J. W. (2012). Citizens, Kant, and corporate responsibility for the environment. In D. G. Arnold \& J. D. Harris (Eds.), Kantian business ethics: Critical perspectives. Northampton, MA: Edward Elgar Publishers

Cooper, J. M. (1980). Aristotle on friendship. In A. Rorty (Ed.), Essays on Aristotle's ethics. Berkeley, CA: University of California Press.

Davenport, C. (2017). Counseling by industry, not staff: EPA chief is dismantling an environmental legacy. New York Times, and reprinted in the Buffalo News, July 2, 2017, p. A4.

De Shalit, A. (1995). Why posterity matters: Environmental policies and future generations. London: Routledge.

Emerson, R. W. (1836). Nature. In R. Spiller et al. (Eds.), The collective works of Ralph Waldo Emerson. Cambridge, MA: Harvard University Press.

Golding, M. P. (1981). Obligations to future generations. In E. Partridge (Ed.), Responsibilities to future generations. Buffalo, NY: Prometheus Books.

Gottlieb, A. (2016). The dream of enlightenment. New York, NY: Liveright Publishing Corporation.

Hale, B. (2017). Rights, rules, and respect for nature. In S. M. Gardiner \& A. Thompson (Eds.), The Oxford handbook of environmental ethics. New York, NY: Oxford University Press.

Inwood, M. J. (1995). Enlightenment. In T. Honderich (Ed.), The Oxford companion to philosophy (pp. 236-237). New York, NY: Oxford University Press.

Jenkins, W., \& Chapple, C. K. (2011). Religion and environment. Annual Review of Environmental Resources, 36, 441-463.

Kant, I. (1784a). What is enlightenment? In A. W. Wood (Ed.), Basic writings of Kant. New York: The Modern Library Classics, The Modern Library.

Kant, I. (1784b). Idea for a universal history with cosmopolitan intent. In A. W. Wood (Ed.), Basic writings of Kant. New York, NY: Modern Library Classics (2001), Random House Inc.
Kant, I. (1785). Fundamental principles of the metaphysics of morals. In A. W. Wood (Ed.), Basic writings of Kant. New York: The Modern Library Classics, The Modern Library.

Kant, I. (1786). What does it mean to orient oneself in thinking?. In Cambridge edition of the writings of Immanuel Kant, 1992. New York, NY: Cambridge University Press.

Kant, I. (1793). Religion within the limits of reason alone. In A. W. Wood (Ed.), Basic writings of Kant. New York: The Modern Library Classics, The Modern Library.

Kant, I. (1797). The metaphysics of morals, M. Gregor (Ed.). Cambridge: Cambridge University Press.

Korsgaard, C. M. (1996). Creating the kingdom of ends. New York, NY: Cambridge University Press.

La Duke, W. (1999). All our relations: Native struggles for land and life. Philadelphia, PA: South End Press.

Leopold, A. (1949, 1966). A Sand County Almanac with essays on conservation from round river. New York, NY: Sierra Club and Ballantine Books.

Muir, J. (1911, 1997). My first summer in the Sierra. In W. Cronon (Ed.) Muir: Nature writings. New York, NY: The Library of America.

Mulgan, T. (2006). Future people. Oxford, UK: Oxford University Press.

Murawski, S. A. (2017). History of New England groundfish fishery. www.nefse.noaa.gov/history/stories/groundfish/grndfsh1.html.

Nolt, J. (2017). Future generations in environmental ethics. In S. M. Gardiner \& A. Thompson (Eds.), The Oxford handbook of environmental ethics (pp. 344-354). New York, NY: Oxford University Press.

O'Neill, O. (1995). Constructions of reason: Explorations of Kant's practical philosophy. New York, NY: Cambridge University Press.

O'Neill, O. (1998). Kant on duties regarding non-rational nature. Proceedings of the Aristotelian Society Supplement, 72, 211-228.

Oregon Wild. (2017a). What is an old-growth forest?. www.oregonwild .org/oregon_forest/old_growth_protection/what-is-an-0ld-growt h-forest.

Oregon Wild. (2017b). Northwest forest plan. www.oregonwild.org/ forests/forest-protection-and-restoration/nwfp.

Rawls, J. (1951). Outline of a decision procedure for ethics. Philosophical Review, 60(2), 177-197. Reprinted in Collected Papers-John Rawls, edited by Samuel Freeman, Harvard University Press, 1999.

Rawls, J. (1958). Justice as fairness. Philosophical Review, 64(1), 3-32. Reprinted in Collected Papers-John Rawls, edited by Samuel Freeman, Harvard University Press, 1999.

Rawls, J. (1980). Kantian constructivism in moral theory. Journal of Philosophy, 77, 515-572. Reprinted in Collected Papers-John Rawls, edited by Samuel Freeman, Harvard University Press, 1999.

Rawls, J. (1987). Idea of an overlapping consensus. Oxford Journal of Legal Studies, 7, 1-25. Reprinted in John Rawls: Collected Papers, edited by Samuel Freeman, Harvard University Press, 1999.

Rawls, J. (1989). Themes in Kant's moral philosophy. From Harvard University Lecture, Reprinted in John Rawls: Collected Papers, edited by Samuel Freeman, Harvard University Press, 1999.

Rawls, J. (2001). Justice as fairness: A restatement. The Belknap Press of Harvard University Press.

Robinson, R. (2016a). Duty and Boycotts: A Kantian analysis. Journal of Business Ethics, published online, Open Access, February 1, 2016. Awaiting print assignment.

Robinson, R. (2016b). Friendships of virtue, pursuit of the moral community, and the ends of business. Journal of Business Ethics, published online, Open Access, August 3, 2016. Awaiting print assignment. 
Robinson, R. (2017). The management Nexus of imperfect duty: Kantian views of friendship, discourse and due diligence. Journal of Business Ethics, published online, Open Access, August 22, 2017. Awaiting print assignment.

Saler, B. (1993). Conceptualizing religion: Immanent anthropologists, transcendent natives, and unbounded categories. Leiden: Brill.

Schuler, D., Rasche, A., Etzion, D., \& Newton, L. (2017). Corporate sustainability management and environmental ethics. Business Ethics Quarterly, 27(2), 213-237. https://doi.org/10.1017/ beq.2016.80.

Sullivan, R. (1994, 1997). An introduction to Kant's ethics. Cambridge: Cambridge University Press.

Taylor, B. (2017). The sacred, reverence for life, and environmental ethics in America. In S. M. Gardiner \& A. Thompson (Eds.), The Oxford handbook of environmental ethics. New York, NY: Oxford University Press.
Thoreau, H. D. (1849). A week on the Concord and Merrimac Rivers. https://archive.org/details/aweekonconcorda00thorgoog/, reprinted in 2011, Princeton University Press, New York, NY.

Thoreau, H. D. (1854). Walden. http://etext.lib.virginia.edu/toc/moden g/public/ThoWald.html.

Thoreau, H. D. (1862). Walking. https://www.org/wp-content/uploa ds/2016/03/Walking-1.pdf.

Train, R. E. (1970). Environmental obligations. National Geographic, 138, 780 .

White, M. D. (2011). Kantian ethics and economics. Stanford, CA: Stanford University Press.

Wood, A. W. (1998). Kant on duties regarding non-rational nature. Proceedings of the Aristotelian Society Supplement, 72, 189-210.

Wood, A. W. (1999). Kant's ethical thought. Cambridge, UK: Cambridge University Press. 